\title{
O sábio e o ignorante. Espinosa e a emenda da vida ${ }^{1}$
}

The Wise and the Ignorant. Spinoza and the Emendation of the Life

\section{Antônio David}

Doutor em Filosofia, USP

\section{RESUMO}

Partindo das figuras do sábio e do ignorante tal como aparecem na obra de Espinosa, busca-se situá-las, na estratégia de exposição de Espinosa, como modelos ou imagens cujo conceito remete à prática. Com isso, procura-se mostrar o lugar central ocupado pelos conceitos de regra de vida e emenda da vida na concepçáo espinosana de liberdade.

\section{PALAVRAS-CHAVE}

Sábio; Ignorante; Regra de vida; Emenda da vida.

\begin{abstract}
Starting from the figures of the wise and the ignorant as they appear on Spinoza's opera, one looks for place then at the Spinoza's strategy of exposition as models or images, which concept refers to the practice. So, one attempts to show the central place occupied by the concepts of rule of life and emendation of the life in Spinoza's conception of liberty.
\end{abstract}

\section{KEY WORDS}

Wise; Ignorant; Rule of Live;

Emendation of the Life.

\footnotetext{
1 Esse artigo é uma versão modificada do apêndice da primeira parte de nossa tese de doutorado. Para efeito de citaçáo da obra de Espinosa, utilizamos as siglas convencionadas entre os comentadores de Espinosa: I) para o Tratado Político, a sigla "TP", seguida do capítulo e do parágrafo; 2) para a Ética, a sigla "E”, seguida do livro e da referência; 3) para o Tratado Teológico-Político, a sigla "TTP", seguida do capítulo e da página na ediçáo consultada; 4) para o Tratado da Emenda do Intelecto, a sigla "TIE" seguida do parágrafo; 5) para os Pensamentos Metafísicos, a sigla "CM", seguida do livro e capítulo; 6) para as cartas, a sigla "Ep.", seguida do número de referência. Os trechos citados podem ter sofrido modificaçôes de traduçáo em relaçáo à edição consultada. Optamos por não traduzir os vocábulos imperium, civitas e conatus. Em relação aos vocábulos e expressóes indicados entre colchetes em latim, optamos por mantê-los declinados, tal como se encontram no trecho citado.
} 
Viver sob a conduta da razão, fruir da beatitude ou da felicidade, ser livre, eis o que, à luz da Ética, "é raro" ou "raramente acontece"2. Ao governo da razáo, cola-se a figura do "sábio" [sapiens], de quem Espinosa afirma, em duas ocasiōes na Ética, à primeira vista em sintonia com a tradição, ser mais potente que o ignorante ${ }^{3}$. Entretanto, como Espinosa fala e escreve conforme a compreensão do vulgo ${ }^{4}$, de imediato impóe-se a dúvida: é de fato possível, como Espinosa parece sugerir, que existam no mundo "sábios" ou "homens livres"? Alguma vez existiu ou pode vir a existir alguém a quem se possa autenticamente chamar de "sábio"?

A fim de respondermos a essa pergunta, e porque é o próprio Espinosa quem prescreve a regra segundo a qual se deve comparar, no estudo de uma obra, os vários empregos de um mesmo termo e os contextos em que são empregados para daí deduzirmos seu significado ${ }^{5}$, é lícito e pertinente debruçarmo-nos sobre uma enigmática formulação presente em uma passagem do Tratado da Emenda do Intelecto:

Se alguém por algum acaso procedesse assim ao investigar a Natureza, a saber, adquirindo, conforme a norma da existente ideia verdadeira, outras ideias na ordem devida, nunca duvidaria da sua verdade, porque a verdade, como mostramos, se revela a si mesma e porque também espontaneamente todas as coisas lhe adviriam. Mas porque isso nunca ou raramente [nunquam, aut raro] acontece [...] (TIE, 44, o destaque é nosso).

Essa passagem tem parentesco com o assunto aqui abordado: aquele trata da liberdade da mente tal como proposto pela Ética; esta trata da capacidade de formar ideias na ordem devida, condição para a prometida emenda do intelecto. Mas sequer é necessário que nos atenhamos a isso. $\mathrm{O}$ ponto para o qual queremos chamar a atenção reside na formulação "nunca ou raramente". Não é curioso que o filósofo conhecido pela sistematicidade com que expõe suas ideias, aquele que faz questáo de dizer "por x entendo y", aquele para quem suas premissas, argumentos e conclusóes são "patentes" e "claras por si mesmas", empregue aqui semelhante expressão? Como explicar a aparente vacilação? Afinal, isso nunca acontece ou raramente acontece? Note-se que a pergunta náo se refere ao conceber, mas ao acontecer. Trata-se de investigar se, para Espinosa, isso efetivamente acontece no mundo. Tal é nosso foco aqui.

\footnotetext{
2 Por exemplo: E, IV, P 35, Esc.; Ibid., IV, P 54, Esc.; Ibid., IV, Cap. 13; Ibid., V, P 42, Esc.

3 Ibid., V, Pref.; Ibid. , V, P 42, Dem. Ao lado do sábio, encontra-se a figura do "homem livre", mencionado numa série de proposiçốes no Livro V da Ética (Ibid., V, P 67-72). Sobre a imagem do sábio na tradição, cf. Chaui, 20II, p. II-66.

4 TIE, 17.

5 TTP, VII.
} 
Essa passagem sugere que o emprego na obra das expressóes "raro" e "raramente" não necessariamente têm o sentido literal. Qual sentido ou quais sentidos pode ter a "raridade" da liberdade, isso depende do contexto no qual o termo é empregado. Segue-se daí que a suposta "raridade" da beatitude depende de que informaçóes nosso autor oferece no curso da obra sobre a liberdade da mente.

Náo faremos um exame exaustivo do Livro V da Ética, posto que tal empreitada foge de nosso escopo. Nem é necessário. A resposta à nossa indagaçáo reside na presença em larga escala, na obra, de uma formulação. Vejamos sua ocorrência precisamente no Livro V: "um afeto está tanto mais em nosso poder, e a Mente tanto menos o padece, quanto mais ele nos é conhecido" (E, V, P 3 , Cor.) ; "quanto mais a Mente é apta a inteligir as coisas pelo terceiro gênero de conhecimento, tanto mais deseja inteligir as coisas por este mesmo gênero de conhecimento" (Ibid., V, P 26) ; "quanto mais cada um é forte neste gênero de conhecimento [o terceiro gênero], tanto mais é consciente de si e de Deus, isto é, tanto mais é perfeito e feliz" (Ibid., V, P 3I, Esc.) ; "quanto mais a Mente intelige as coisas pelo segundo e pelo terceiro gênero de conhecimento, tanto menos padece dos afetos que são maus, e menos teme a morte" (Ibid., V, P 38) ; "quanto mais cada coisa tem mais perfeição, tanto mais age e menos padece, e, ao contrário, quanto mais age, tanto mais é perfeita" (Ibid., V, P 40) ; "quanto mais a Mente goza deste Amor divino ou felicidade, tanto mais intelige (pela prop. 32 desta parte)" (Ibid., V, P 42, Esc.). Peça chave na Ética, a fórmula "quò... è magis/plus..." ("quanto mais... tanto mais/ maior...") é abundante na obra, estando presente em todos os cinco livros ${ }^{6}$. O ponto é que todas essas ocorrências igualmente remetem à noção de graus de perfeição ou de realidade, sintetizado na proposição I, P II: "quanto mais realidade cabe à natureza de alguma coisa, tanto mais forças tem de si para existir" (Ibid., I, P II, Esc.) .

Tendo na física dos fluidos o seu paradigma ${ }^{7}$, Espinosa concebe o conatus como pars, o que é da tradição agostiniana e escolástico-tomista, mas dela afastando-se na medida em que, para Espinosa, o conatus não é determinado grau de participação no ser, cristalizado, mas exprime graus de realidade em contínua variaçáa ${ }^{8}$. Com isso, as coisas finitas assim são ditas porque podem ser delimitadas por outra de mesma

6 P. ex., Ibid., I, Ap.; Ibid., II, P I3, Esc.; Ibid., III, P ı; Ibid., IV, P 20. Dependendo do que é dito, além da consequente variável inversa, pode ainda ocorrer nas variáveis "quanto menos... tanto mais/maior..." e sua inversa, "quanto mais... tanto menos/menor...".

7 As concepçôes e mesmo definiçôes de conatus em Espinosa, Descartes e Hobbes dependem do paradigma da física adotado: em Descartes, porque o paradigma é a física do choque, a primeira paixão é a admiração; porque em Hobbes é a física da pressão, o conatus é definido como resistência, no sentido mais fiel do termo; em Espinosa, temos uma física dos fluidos, por isso que primeiro vem os afetos de alegria e tristeza.

8 Cf. Chaui, 2003, p. I28-I5I; Ibid. , 20II, p. 203. 
natureza ${ }^{9}$, mas essa delimitação varia conforme são afetadas de muitas maneiras por muitas outras coisas ${ }^{10}$. Segue-se daí uma contínua variação [continua variatio $]^{11}$ no conatus: "os afetos podem compor-se uns com os outros de tantas maneiras, e daí podem originar-se tantas variaçóes, que não podem ser definidos por nenhum número" (Ibid., III, P 54, Esc.). A fórmula “quanto mais... tanto mais/maior..." exprime, pois, a contínua variação a que todas as coisas singulares estão submetidas.

Se a fórmula permite conceber um ponto máximo, o que pode induzir o leitor a pensar que é possível atingi-lo ${ }^{12}$, Espinosa alerta o leitor, ao introduzir a noção de contínua variação, de que "conforme mudamos para melhor ou pior, tanto mais somos ditos [dicimur] felizes ou infelizes" (E, V, P 39, Esc.). Note-se bem que, para Espinosa, "somos ditos" felizes. Ademais, cumpre advertir que "a força pela qual o homem persevera no existir é limitada e é infinitamente superada pela potência de causas externas" (Ibid., IV, $\mathrm{P}_{3}$, Def. 3), e que "não está em poder de cada homem usar sempre da razão e estar no nível supremo da liberdade humana [summo humanae libertatis sastigio]" (TP, II, 8, o destaque é nosso). Assim, em face da pergunta que de início fizemos, a resposta é negativa: "não houve jamais alguém de ânimo tão potente e tấo íntegro que não estivesse alguma vez, principalmente quando mais preciso era pela fortaleza de ânimo, enfraquecido e se deixasse vencer" (Ibid., VI, 3).

Por tudo isso, e à luz da ontologia espinosana, pensamos que a aparente vacilação de que há pouco falávamos denota um uso eufemístico. Escrevendo conforme a compreensão de um leitor para quem a figura do "sábio" é regada de prestígio, Espinosa a introduz na obra na condiçáo de modelo da natureza humana [natura bumane exemplar]:

Quanto ao bem e ao mal, também não indicam nada de positivo nas coisas consideradas em si mesmas, e não são nada outro além de modos de pensar ou noçôes que formamos por compararmos as coisas entre si. [...] porque desejamos formar uma ideia de homem que observemos como modelo da natureza humana [nature humana exemplar], nos será útil reter estes mesmos vocábulos no sentido em que disse. E assim, por bem entenderei, na sequência, o que sabemos certamente ser meio [medium] para nos aproximarmos [accedemus] mais e mais do modelo de natureza humana que nos propomos. Por mal, porém, isso que certamente sabemos que nos impede de reproduzir o mesmo modelo. Ademais, diremos que os homens são mais perfeitos ou mais imperfeitos enquanto aproximam-se mais ou menos desse modelo [Deinde homines perfectiores, aut imperfectiores dicemus, quatenus ad hoc idem exemplar magis, aut

\footnotetext{
9 E, I, Def. 2.

${ }^{10}$ Ibid., II, Def. 4; Ibid., III, Post. 2.

${ }^{11}$ Ibid., V, P 39, Esc.

${ }^{12} \mathrm{Na}$ obra, o grau máximo de perfeição aparece sob a designação "cume da sabedoria" (TIE, 3I; TP, I, I).
} 
minùs accedunt]. Pois, antes de tudo, deve-se notar que, quando digo que alguém passa de uma menor a uma maior perfeição, e inversamente, não entendo que mude de uma essência ou forma para uma outra (E, IV, Pref.).

A noção de modelo da natureza humana denota a condição do que, na passagem antes citada, é dito ser "raro": um concebível sem existência real no mundo, mas do qual podemos nos aproximar. Em outras palavras, se Espinosa introduz na obra a figura do "sábio" ou do o homem "totalmente livre" e discerne o que ele é capaz, disso não é lícito concluir que possa ter tido ou que possa vir a ter existência real, tal como imaginam ou julgam os homens, em particular os filósofos ${ }^{13}$.

Com isso, a sabedoria está muito mais ligada à possibilidade de se agir com sabedoria em tal ou tal situação do que à possibilidade de efetivamente existirem homens capazes de fruir da beatitude ou felicidade de maneira continua e irreversivel ${ }^{14}$. Tal é a imagem do sábio. Pela mesma razão, também "o ignorante” é uma imagem.

Sendo assim, no que consistiria o conceito do qual o "sábio" é imagem, e que está na base de um agir sábio em tal ou tal situação? Segundo Espinosa, não obstante o sábio e o ignorante serem igualmente determinados a agir ${ }^{15}$, o sábio, "enquanto

${ }^{13}$ TP, II, II. A considerar o que no Tratado Teológico-Politico é dito, há à primeira vista uma dificuldade particularmente quanto à figura de Jesus Cristo. Diz Espinosa: "embora se compreenda que Deus pode, sem dúvida, comunicar-se imediatamente com os homens, pois comunica a sua essência à nossa mente sem precisar de nenhum meio corporal, todavia, para que um homem percebesse só pela mente certas coisas que náo estáo contidas nos primeiros princípios do nosso conhecimento, nem deles se podem deduzir, a sua mente teria de ser por força superior e, de longe, mais perfeita que a mente humana. Assim sendo, não creio que alguém tenha atingido tanta perfeição, a não ser Cristo, a quem os preceitos divinos que conduzem os homens à salvação foram revelados imediatamente, sem palavras nem visóes: Deus manifestou-se, portanto, aos apóstolos através da mente de Cristo como outrora a Moisés por meio de uma voz que vinha do ar. E assim, à voz de Cristo, tal como àquela que Moisés ouvia, pode chamar-se a Voz de Deus. Nesse sentido, podemos afirmar que a Sabedoria divina, isto é, a Sabedoria que é superior à do homem, assumiu em Cristo a natureza humana e Cristo foi o caminho da salvação." (TTP, I, p. 22, o destaque é nosso; cf. também: Ibid., III, p. 74). A passagem sugere - apenas sugere, náo afirma de maneira assertiva - que Cristo teria atingido aquele grau de perfeição de que fala a Ética sob a rubrica de "homem livre". Com isso, e à luz do que é dito na obra sobre o assunto e que aqui reproduzimos, Cristo parece ser o único caso de "homem livre" de que se tem notícia historicamente. Pensamos que essa dificuldade é facilmente dirimida quando se leva em conta duas coisas. Em primeiro lugar, como consequência do método ex sola Scriptura, sabemos que Espinosa está a falar de Cristo tal como a Bíblia o apresenta, de modo que, quando fala de Cristo, é como se Espinosa estivesse falando de uma personagem. Náo surpreende que seja assim, afinal, no Tratado Teológico-Político, Espinosa discorre sobre personagens míticas (Adão e Caim) no mesmo tom com que discorre sobre Cristo e todas as demais personagens. Em segundo lugar, pela primeira regra de vida estabelecida no parágrafo i7 do Tratado da Emenda do Intelecto, qual seja, falar conforme a compreensăo do vulgo, sabemos que Espinosa emprega vocábulos e argumentos conforme sua acepçáo vulgar. Pela historiografia, sabemos ainda que os leitores prioritários de Espinosa são os calvinistas heterodoxos em seu próprio país (cf. Meinsma, I983). Sobre a figura de Jesus Cristo em Espinosa, cf. Mathéron, 1971. Sobre a estratégia de exposição de Espinosa e a centralidade do conceito de vulgo, abordamos esse tópico em nossa tese de doutorado (Introdução).

${ }^{14}$ Cf., por exemplo, Ep. 44, a mençáo a Tales de Mileto.

15 TP, II, 5; Ibid., II, 8; Ibid., III I8. 
considerado como tal", é "mais potente que o ignorante" ${ }^{16}$. A razão é sua maior aptidão ao múltiplo simultâneo:

É do homem sábio usar as coisas e, o quanto possível, deleitar-se com elas. É do homem sábio, insisto, refazer-se e gozar moderadamente de comida e bebida agradáveis, assim como cada um pode usar, sem qualquer dano a outrem, dos perfumes, da amenidade dos bosques, do ornamento, da música, dos jogos esportivos, do teatro e de outras coisas deste tipo. Pois o Corpo humano é composto de muitíssimas partes de natureza diversa, que continuamente precisam de novo e variado alimento para que o Corpo inteiro seja igualmente apto a todas as coisas que podem seguir de sua natureza e, por conseguinte, para que a Mente também seja igualmente apta a inteligir muitas coisas em simultâneo [plura simul]. E assim esta maneira de viver [vivendi institutum] convém otimamente com nossos princípios e com a prática comum; por isso, se não é a única, esta regra de vida [vivendi ratio] é a melhor e cabe recomendála de todas as maneiras, e nem é preciso tratar disso mais clara nem prolixamente (E, IV, P 45, Esc., o destaque é nosso).

Se o sábio só é sábio por ser mais apto ao múltiplo simultâneo, tal aptidão deriva, como se vê nessa passagem, não da fruição contínua e irreversível da beatitude — pois, como vimos há pouco, contínua é a variação em que vivemos dada a potência das causas externas que superam a nossa —, mas de uma ratio vivendi, isto é, uma "regra de vida". O que devemos entender por "regra de vida"? O exame desse conceito exige que se leve em conta o emprego, na obra, das expressóes vera vita [verdadeira vida] e ratio vivendi [regra de vida], bem como de algumas outras expressóes correlatas.

No Escólio da IV, P 73, ao abordar a "verdadeira liberdade do homem", a qual é referida à fortaleza de ânimo (combinação de firmeza e generosidade), Espinosa faz menção às coisas que dizem respeito à "verdadeira vida e religião" [vera vita \& Religio]: que "o homem forte não tem ódio a ninguém, não se ira com ninguém, não inveja, não se indigna, não tem despeito por ninguém e de modo algum se ensoberba”. A estas palavras, Espinosa acrescenta um argumento fundamental:

O homem forte considera, primeiramente [apprimè], que tudo segue da necessidade da natureza divina, e por conseguinte tudo o que ele pensa ser molesto e mau, e tudo que além disso parece ímpio, horrendo, injusto e torpe, originase de que concebe as próprias coisas desordenada, mutilada e confusamente, e por isso ele se esforça primeiramente [apprimè] para conceber as coisas como

\footnotetext{
16 "Por outro lado, o sábio, enquanto considerado como tal, dificilmente tem o ânimo comovido; mas, cônscio de si, de Deus e das coisas por alguma necessidade eterna, nunca deixa de ser, e sempre possui o verdadeiro contentamento do ânimo" (E, V, P 42, Esc.). A passagem em questão é relevante para a defesa de nosso ponto de vista. Pois, se o sábio "nunca deixa de ser, e sempre possui o verdadeiro contentamento do ânimo" (o destaque é meu), note-se que aqui Espinosa faz menção ao sábio "enquanto considerado como tal" [quatenus ut talis consideratur]. Essa expressão indica estar Espinosa falando de uma abstração.
} 
elas são em si e para afastar o que impede o verdadeiro conhecimento, tal como o Ódio, a Ira, a Inveja, o Escárnio, a Soberba e outras coisas deste tipo, que mostramos no que precede; e, assim, esforça-se o quanto pode, como dissemos, para agir bem e alegrar-se (E, IV, P 73, Esc., o destaque é nosso).

Ao cabo, informa nosso autor que demonstrará "até que ponto se estende a virtude humana para conseguir isso, e o que ela pode" (Ibid.) ${ }^{17}$. Especialmente relevante nessa passagem é a expressão apprimè, "primeiramente", pois remete ao conceito do qual a sabedoria é imagem. O exercício da liberdade consiste em conceber, em cada situação, que tudo segue da necessidade da natureza divina (afastando com isso a imagem da vontade livre, do vício e da culpa), isto é, em conceber as coisas como elas são em si (afastando com isso o que impede o verdadeiro conhecimento, ou seja, o não conceber as coisas em ordem e na sua singularidade).

No Tratado Teológico-Político, Espinosa argumenta de que maneira Salomão, dito "o Rei Sábio", concebe a verdadeira vida à maneira da Ética. Para ele, a "fonte da verdadeira vida [vera vita fons]" reside no entendimento humano. Segundo Espinosa, Salomão "ensina por palavras bem explícitas que o entendimento dá ao homem a beatitude e a felicidade e bem assim a verdadeira tranquilidade de ânimo [veram animi tranquilitatem]". Amparando-se em Salomão, argumenta Espinosa que a sabedoria é o entendimento [sapientia sive intellectus] e contrapóe aos ímpios [impii] não os piedosos, mas os sábios [sapiens], e conclui:

Por isso, a felicidade e a tranquilidade de quem cultiva o entendimento natural, de acordo ainda com Salomão, não depende do império da fortuna [ab imperio fortunae] (isto é, do auxílio externo de Deus), mas sim e principalmente da sua própria virtude interior [a sua interna virtute] (isto é, do auxílio interno de Deus). Por outras palavras, conserva-se sobretudo através da vigilância, da atividade e dos bons conselhos [vigilando, agendo et bene consulendo] (TTP, IV, p. 77) ${ }^{18}$.

Em duas passagens, Espinosa aborda aquilo que se contrapõe à verdadeira vida: de um lado, a superstiçáo, que "odeia acima de tudo os que cultivam a verdadeira

\footnotetext{
${ }^{17}$ Cf. também Ibid., IV, Ap., Cap. 32.

${ }^{18}$ O ponto central da menção a Salomão é que o culto segundo a verdadeira religiáo pode ser tanto o "culto", tradicionalmente entendido, como pode ser o culto no sentido etimológico do termo, isto é, um cultivar, uma conduta.
} 
ciência e a verdadeira vida" (Ibid., II, p. 32); de outro, a inveja e a má vontade ${ }^{19}$, que leva os homens a apetecer a glória de serem os únicos a estar bem ${ }^{20}$.

Feitos esses apontamentos, emerge inevitavelmente a questão: até que ponto se pode alcançar a "verdadeira vida"? A pergunta é tão mais importante quando se considera que, a depender do que se entende por "verdadeira vida", ela vocaliza, com outras palavras, a mesma pergunta que já fora por nós respondida na negativa. Para responder a essa questão, cumpre adentrarmos no terreno da ratio vivendi e, quando for ocasião, voltaremos ao terreno da vera vita. Do encontro entre uma e outra surgirá a resposta.

Entremos no terreno da regra de vida. Para tanto, é indispensável recorrer ao capítulo IV do Tratado Teológico-Político, dedicado à lei divina. Com vistas a distinguir lei humana de lei divina, Espinosa explicita o duplo sentido de "regra de vida": pode-se entender a regra de vida por decisão própria [ex proprio decreto], isto é, regida pela razão, e a regra de vida por decisão alheia [ex alieno decreto], isto é, externamente imposta. Aquela pertence à Ética; esta, dirá Espinosa tratar-se da regra com a qual os legisladores "procuram conter o vulgo, tanto quanto é possível fazêlo, assim como se segura um cavalo com a ajuda de um freio”. Em resumo:

Não sendo, portanto, a lei mais do que uma regra de vida [ratio vivendi] que os homens prescrevem a si mesmos ou a outros com determinada finalidade, parece que a devemos distinguir em humana e divina. Por lei humana, entendo uma regra de vida [rationem vivendi] que serve unicamente para manter a segurança do indivíduo e da coletividade; por lei divina, entendo uma regra [ratio] que diz respeito apenas ao soberano bem, isto é, ao verdadeiro conhecimento e amor de Deus (TTP, IV, p. 67) ${ }^{21}$.

Se a regra de vida é de fato central na obra, a passagem dá a entender haver um dilema entre, de um lado, ser conduzido pela razáo e, de outro, e ser contido da mesma maneira que um cavalo é contido pelas rédeas; com isso, parece confirmar e

\footnotetext{
19 "A verdadeira felicidade e beatitude do indivíduo consiste unicamente na fruição do bem e não, como é evidente, na glória de ser o único a fruir quando os outros dele carecem; quem se julga mais feliz só porque é o único que está bem, ou porque é mais feliz e mais afortunado que os outros, ignora a verdadeira felicidade e beatitude. Porque a alegria que assim se experimenta, a menos que seja infantil, náo pode resultar de outra coisa que năo seja a inveja e a má vontade. Exemplificando: a verdadeira felicidade e beatitude dum homem consiste apenas na sabedoria e no conhecimento da verdade e não em ser mais sábio do que os outros ou no fato de eles não possuírem o verdadeiro conhecimento, pois isto náo acrescenta absolutamente nada à sua sabedoria, que o mesmo é dizer, à sua verdadeira felicidade. Quem, por conseguinte, se regozija por tal fato, regozija-se com o mal dos outros, é invejoso e mau e não conhece nem a verdadeira sabedoria nem a tranquilidade da verdadeira vida [verae vitae tranquillitatem]” (Ibid. , III, p. 50 ).

${ }^{20}$ Daí que a vocação dos hebreus não pode ter sido serem os únicos a usufruir da verdadeira vida (cf. Ibid., III, p. 54).

${ }^{21}$ Espinosa inicia o argumento afirmando que a palavra lei aplica-se às coisas naturais "metaforicamente" [per translationem]. Isso porque, como vimos anteriormente, a "primeira significaçáa” da palavra é dada pelo vulgo.
} 
mesmo reforçar a polarização entre o sábio e o ignorante. Assim vista, a passagem parece sugerir que nos equivocamos ao recusar o dualismo que separa o "sábio" do "ignorante". Corrobora essa hipotética leitura o que é dito no Escólio da IV, P 66, que trata do apetecer sob a conduta da razão. Após ter argumentado que o homem só conduzido pelo afeto "faz aquilo que ignora ao máximo", ao passo que o homem conduzido pela razão "não se comporta à maneira [morem] de ninguém, a não ser à sua própria, e faz somente o que sabe ser o primordial na vida [in vitâ prima], e que por isso ele deseja ao máximo", Espinosa dirá: “assim, ao primeiro chamo servo, porém chamo livre ao segundo, sobre cujo engenho e regra de vida [vivendi ratione] gostaria de fazer ainda algumas observaçôes" (E, IV, P 66, Esc.) ${ }^{22}$. Essas palavras reconduzem o sábio ao lugar de onde quisemos tirá-lo?

Para responder a essa questão, cumpre examinar com atenção, na obra de Espinosa, as duas dimensóes da regra de vida. A primeira, ex proprio decreto, também chamada de "verdadeira regra de vida", resume-se a muito poucos preceitos: "a purificação da vontade, a prática, ou seja, o hábito das virtudes, que o mesmo é dizer das boas açóes e, finalmente, a ajuda prestada aos pobres [inopi]" (TTP, V, p. 8I). Vale notar que seu avesso - a discórdia, o ódio e o desejo de dominar através das invençóes — é a prática dos homens tal como testemunhada in loco por Espinosa em sua própria época ${ }^{23}$. Especialmente interessante é o fato de essa regra de vida poder ser alcançada, ou adotada tanto por meio da luz natural como por meio da religiáo:

As verdades de natureza meramente especulativa que a Escritura pretende ensinar são, essencialmente, as seguintes: existe um Deus, ou seja, um ser que fez, dirige e sustenta todas as coisas com suma sabedoria, que cuida dos homens, ou melhor, daqueles que vivem piedosa e honestamente, já que aos outros os castiga com numerosos suplícios e os aparta dos bons. Tudo isso a Escritura demonstra apenas pela experiência, quer dizer, pelas histórias que narra, sem apresentar nenhuma definiçáo dessas coisas e adaptando todas as palavras e todos os argumentos à compreensão da plebe. É que, muito embora a experiência não possa fornecer de tais coisas nenhum conhecimento claro nem ensinar o que é Deus e de que forma ele conserva e dirige todas as coisas e cuida dos homens, ela pode pelo menos instruir e esclarecer os homens o suficiente para lhes imprimir no ânimo a obediência e a devoçáo. Assim sendo, creio que resulta claro a quem e por que razão é necessária a fé nas histórias que vêm nos Livros Sagrados. É, com efeito, evidente, pelo que acabei de expor, que o conhecimento e a fé nessas histórias são extremamente necessários ao vulgo,

\footnotetext{
22 As observaçóes de que faz menção no final do Escólio são feitas numa sequência que vai das proposiçóes IV, P 67 a 73, exceto a proposição IV, P 68. Ao cabo, No Apêndice da mesma Parte, Espinosa promete fazer um resumo em capítulos daquilo que dispersamente apresentou como a "correta regra de vida [rectâ vivendi ratione]" ( Ibid., IV, Ap.).

${ }^{23}$ Ibid., VII, p. II4 .
} 
cuja maneira de ser é incapaz de perceber as coisas clara e distintamente. Por outro lado, quem não acredita nessas histórias porque não crê que Deus exista e providencie pelas coisas e pelos homens é um ímpio. Porém, aquele que as ignora e todavia reconhece pela luz natural que Deus existe, etc., e observa, além disso, a verdadeira regra de vida [veram vivendi rationem] esse possui inteiramente a beatitude, mais até do que o vulgo, pois além de opinióes verdadeiras tem, acima de tudo, um conceito claro e distinto (TTP, V, p. 90).

Dessa passagem, são dignas de nota duas coisas: primeiro, que o simples dualismo pio versus ímpio, à maneira da tradição, é afastado e, em seu lugar, subsiste uma tríade, com um terceiro elemento entrando em cena, qual seja, daquele que ignora as histórias mas, porque reconhece Deus pela luz natural etc., observa a verdadeira regra de vida; segundo, que ambos, tanto aquele que reconhece a luz natural como o vulgo, possuem a "beatitude", embora aquele a possua "mais", num sentido muito preciso: porque, além das opiniôes verdadeiras — que, supóe-se, o vulgo também tem, ao contrário do que julgavam os antigos judeus ${ }^{24}$ e, podemos acrescentar, a tradição - , aquele tem, "acima de tudo, um conceito claro e distinto".

$\mathrm{O}$ fato de Espinosa ter dito aqui, aberta e explicitamente, que o vulgo, entendido como o comum dos homens, também possui a beatitude, não é de pouca importância ${ }^{25}$. Quanto a isso, atente-se para a parte final do próprio título do capítulo XIII do Tratado Teológico-Político: "mesmo da natureza de Deus, ela não ensina senáo aquilo que os homens podem imitar [imitari] através de uma certa regra de vida [certa vivendi ratione]". Se a regra de vida pode ser imitada da natureza de Deus, isso permite que o conceito de "verdadeira vida" estenda-se do campo da luz natural ao campo vulgar, por assim dizer, o que é realizado nos capítulos XIII e XIV do tratado. Neles, o conceito de verdadeira vida dá lugar ao conceito de "modelo de verdadeira vida" [vera vitae exemplar], que é Deus, tal como as principais narrativas históricas o apresentam.

Segundo Espinosa, a divina justiça e caridade são os "atributos que os homens podem imitar [imitari] mediante uma certa regra de vida [certe vivendi ratione]" e, referindo-se a João, afirma nosso autor que "quem tem a virtude da caridade possui realmente Deus e o conhece [noscere]" (TTP, XIII, p. 2II, o destaque é nosso) ${ }^{26}$.

\footnotetext{
${ }^{24}$ Ibid., V, p. 92.

${ }^{25}$ Veja-se, por exemplo, as passagens em que Espinosa mostra de que maneira o vulgo era exortado a seguir a verdadeira regra de vida, a qual, no caso dos hebreus, "foi mais uma escravidáo que uma verdadeira liberdade". Cf. Ibid., II, p. 45-49.

${ }^{26}$ Cf. também Ibid., XIV, p. 219. Conhece-o porque tem a virtude da caridade, e não por ter atingido o cume da sabedoria. Como contrapartida, dirá Espinosa: "se ele é fogo, espírito, luz, pensamento, etc., isso năo tem nada a ver com a fé, tal como o saber por que é que ele é modelo de verdadeira vida, se é porque tem uma vontade justa e misericordiosa ou porque todas as coisas são e agem por ele e, consequentemente, se é também por ele que nós compreendemos e vemos o que é verdadeiro, justo e bom. Seja o que for que cada um pense a respeito de tais questóes, é indiferente. [...] Em segundo lugar, também não interessa para a fé se uma pessoa acredita que Deus está em toda parte em virtude da sua essência ou da sua potência, se refere as coisas
} 
No capítulo XIV, concluirá Espinosa que todos aqueles que obedecem a Deus, seguindo essa regra de vida [vivendi ratione], "obtêm a salvação, ao passo que os outros, os que vivem sob o império dos prazeres [sub imperium voluptatum vivunt], estão perdidos", e que "se os homens não acreditassem firmemente nisso, não haveria nenhuma razão para preferirem obedecer antes a Deus do que submeterem-se aos prazeres [Deo potius quam voluptatibus obtemperare mallent]" (Ibid., XIV, p. 220 $)^{27}$.

Tendo mostrado que a verdadeira regra de vida, aquela ex proprio decreto, é também compartilhada pelo vulgo, aqui entendido como o comum dos homens, ainda assim cumpre examinar de que maneira exatamente a verdadeira regra de vida é adquirida pela luz natural, e se essa aquisição permite reestabelecer o lugar do "sábio" que outrora procuramos criticar. Para tanto, não há melhor passagem na obra de Espinosa do que o Escólio da V, P ıo, que trata do poder de ordenar e concatenar as afecçóes do corpo segundo a ordem do intelecto, quando nos defrontamos com afetos contrários à nossa natureza. Fazendo menção à "reta regra de viver ou certos dogmas de vida”, diz Espinosa no Escólio:

Por este poder de corretamente ordenar e concatenar as afecçôes do Corpo, podemos fazer com que não sejamos facilmente afetados por afetos maus. Pois (pela prop. 7 desta parte) requer-se uma maior força para coibir Afetos ordenados e concatenados segundo a ordem do intelecto do que para coibir os incertos e vagos. Portanto, o melhor que podemos fazer enquanto náo temos o conhecimento perfeito de nossos afetos é conceber uma reta regra de viver ou certos dogmas de vida [rectam vivendi rationem, seu certa vitae dogmata], confiá-los à memória e aplicá-los continuamente às coisas particulares que frequentemente se apresentam na vida, para que assim nossa imaginação seja largamente afetada por eles e eles nos estejam sempre à mão [ut sic nostra imaginatio latè iisdem afficiatur, \& nobis in promptu sint sempe]. P. ex.: pusemos entre os dogmas de vida (ver prop. 46 da parte IV com seu esc.) vencer o Ódio com Amor ou Generosidade, e não compensá-lo com Ódio recíproco. E para que tenhamos esta prescriçáo da razão sempre à mão quando for preciso, cumpre pensar e meditar frequentemente nas injúrias comuns dos homens, bem

pela liberdade ou pela necessidade da natureza, se prescreve leis tal como faz um príncipe ou se as ensina como verdades eternas, se o homem obedece a Deus por livre-arbítrio ou pela necessidade do decreto divino, se, enfim, a recompensa dos bons e o castigo dos maus é natural ou sobrenatural. Do ponto de vista da fé, repito, essas questôes e outras semelhantes nấo têm nenhuma importância, seja qual for a maneira como são entendidas, contanto que daí se náo tente extrair maior liberdade para pecar ou para ser menos obediente a Deus." (Ibid., XIV, p. 220 ).

27 Dada a contraposiçáo entre a regra de vida e o imperium da volumptas, é muito curioso que a vocábulo volumptas não seja sequer mencionado na Ética. Tampouco no Tratado da Emenda do Intelecto o termo figura. Observamos a ocorrência do termo em poucas passagens da obra: BT, XVII (no qual é exposta a filosofia de Aristóteles); TP, II, 6; TTP, II, p. 46; Ibid., XII, p . I97 ; Ibid., XVI, p. 239 e 24I. Em todas elas, o argumento é o mesmo: os homens deixam-se entregar aos prazeres, ou são por eles arrastados. 
como na maneira e na via pela qual são repelidas otimamente pela Generosidade; com efeito, assim uniremos a imagem da injúria à imaginação deste dogma, e ele nos estará sempre à mão (pela prop. I8 da parte II) quando sofrermos injúria. De fato, se também tivermos à mão a regra do que nos é verdadeiramente útil [rationem nostri veri utilis], bem como do bem que segue da amizade mútua e da sociedade comum, e, além disso, levarmos em conta que da reta regra de viver se origina o sumo contentamento do ânimo [ex rectâ vivendi ratione summa animi acquiescentia oriatur] (pela prop. 52 da parte IV), e que os homens, como o resto, agem pela necessidade da natureza; entáo a injúria, ou seja, o Ódio que dela costuma originar-se, ocupará uma parte mínima da imaginação e será facilmente superada [minimam imaginationis partem occupabit, \& facilè superabitur]; e se a Ira, que costuma originar-se das maiores injúrias, não for tão facilmente superada, contudo, ainda que com flutuação do ânimo [quamvis non sine animi fluctuatione], ela será superada [superabitur] em um espaço de tempo muito menor do que se não tivéssemos meditado previamente sobre estas coisas, como é patente pelas prop. 6, 7 e 8 desta parte. Do mesmo modo, cumpre pensar na Firmeza para que se derrube o Medo; a saber, cumpre enumerar e imaginar frequentemente os perigos comuns da vida e a maneira como podem ser otimamente evitados e superados pela presença de espírito e pela fortaleza. É de notar, porém, que ao ordenar nossos pensamentos e imagens [nobis in ordinandis nostris cogitationibus, \& imaginibus], cumpre-nos sempre prestar atençâo (pelo corol. da prop. $63 \mathrm{da}$ parte IV e prop. 59 da parte III) àquilo que é bom em cada coisa, para que assim sejamos determinados a agir sempre pelo afeto de Alegria [ut sic semper ex Laetitiae affectu ad agendum determinemur]. P. ex.: se alguém vê que persegue excessivamente [nimis] a glória, que ele pense em seu uso correto [recto $u s u$, no fim em vista do qual cabe persegui-la e nos meios para poder adquirila, mas não em seu abuso, vanidade [abusu, \& vanitate], na inconstância dos homens ou em outras coisas deste tipo, sobre as quais ninguém pensa senão por perturbação do ânimo; com efeito, tais pensamentos afligem ao máximo os maximamente ambiciosos quando estes desesperam de alcançar a honra que ambicionam; e, ao vomitar Ira, querem parecer sábios. Por isso é certo serem ao máximo desejosos de glória aqueles que ao máximo clamam contra o seu abuso e a vanidade do mundo. E isto não é próprio somente aos ambiciosos, mas é comum a todos aos quais a fortuna é adversa e que são impotentes de ânimo. Pois, sendo pobre, também o avaro não cessa de falar do abuso do dinheiro e dos vícios dos ricos, e não faz outra coisa senão afligir-se e mostrar aos outros que suporta com dificuldade não apenas sua pobreza, mas igualmente as riquezas alheias. Assim também aqueles que sáo mal recebidos pela amante não pensam em nada além da inconstância das mulheres, de seu ânimo falaz e de seus outros decantados vícios, os quais eles rapidamente devolvem ao esquecimento táo logo voltem a ser acolhidos pela amante. Portanto, quem se aplica em moderar seus afetos e apetites só pelo amor da Liberdade [Qui itaque suos affectûs, \& appetitûs ex solo Libertatis amore moderari studet] empenha-se, o quanto pode, em conhecer as virtudes e suas verdadeiras causas, e em encher o ânimo do gozo que se origina do verdadeiro 
conhecimento delas; mas de jeito nenhum em contemplar os vícios humanos, difamar os homens e regozijar-se com uma falsa espécie de liberdade. E aquele que diligentemente observar estas coisas (e, de fato, não são difíceis) e exercitálas [diligenter observabit (neque enim difficilia sunt), \& exercebit], em breve espaço de tempo poderá dirigir suas açóes, no mais das vezes [plerumque], pelo império da razão [ex rationis imperio] (E, V, P Io, Esc.).

Dessa longa passagem, podemos tirar quatro importantes conclusóes. Em primeiro lugar, e em sintonia com o que se lê no parágrafo I7 do Tratado da Emenda do Intelecto, a regra de vida é necessária enquanto (na prática, porque) não temos o conhecimento perfeito de nossos afetos - ou seja, sua legitimidade ampara-se na impossibilidade prática da consecução daqueles objetivos. Em segundo lugar, ela deve ser aplicada às coisas singulares que frequentemente se apresentam na vida, "para que assim nossa imaginação seja largamente afetada por eles" — ou seja, sua validade está associada ao universo da prática. Em terceiro lugar, assim procedendo, o ódio "ocupará uma parte mínima da imaginação e será facilmente superada" por um afeto contrário. Assim, "ainda que com flutuação do ânimo", nossos pensamentos e imagens seráo ordenados, "para que assim sejamos determinados a agir sempre pelo afeto de Alegria”. Note-se que, mesmo aquele que consegue ao fim e ao cabo dirigir suas ações pela razão, ele o faz não sempre, mas "na maior parte do tempo" - ou seja, seu terreno é inteiramente o da vida afetiva. Em quarto e último lugar, esse proceder consiste em um empenho [studeo] em moderar os afetos e apetites "só pelo amor da Liberdade"28.

Desse quarto ponto, e à luz dos demais, podemos extrair uma lição fundamental sobre a atividade da liberdade em Espinosa: porque imaginamos uma liberdade total e ela é causa em nós de alegria, de que somos cônscios, somos movidos a buscá-la; e, não obstante não atinjamos nosso objetivo (imaginário), essa busca é, ela própria, o objetivo perseguido (conceitual/intelectual). Em outras palavras, no esforço por alcançar a liberdade da mente, e só nele, reside a liberdade possível. Nesses termos, podemos dizer que, em Espinosa, a liberdade é uma aptidão ${ }^{29}$.

Como se vê, tais apontamentos a partir da Ética são fundamentais para a devida e justa caracterização da sabedoria em Espinosa. Todavia, aquele que a nosso juízo

\footnotetext{
${ }^{28}$ Nesse contexto, o verbo studeo designa um direcionamento do conatus, sendo por isso dele correlato.

${ }^{29}$ É o que sugere, por exemplo, o emprego do verbo fero ("suportar", "resistir") no Capítulo 32 do Apêndice do Livro IV: "Mas a potência humana é bastante limitada e infinitamente superada pela potência das causas externas; e, assim, não temos um poder absoluto de adaptar para nosso uso as coisas que estấo fora de nós. No entanto, suportaremos com igual ânimo [aequo animus feremus] as coisas que nos ocorrerem contra o que postula a regra da nossa utilidade se estivermos cônscios de que cumprimos nossa funçáo, de que a potência que temos não pôde estender-se até o ponto de podermos evitá-las, e de que somos parte da natureza inteira, cuja ordem seguimos" (Ibid., IV, Ap., Cap. 32).
} 
é o conceito-chave para o encaminhamento da questão foi empregado por Espinosa apenas uma vez; não na Ética, mas no Tratado Teológico-Político ${ }^{30}$. Na sequência da passagem antes citada em que distingue entre o pio, o ímpio e aquele que, apesar de ignorar as narrativas históricas, segue a verdadeira vida, dirá Espinosa que, assim como este possui inteiramente a beatitude, da mesma maneira de nada vale ler as narrativas da Escritura e nelas depositar uma fé incondicional sem atender à doutrina que a mesma Escritura tenta por esse meio ensinar, ou seja, sem observar a verdadeira regra de vida. Nesse momento, Espinosa afirma que estes não procuram "emendar a sua vida [vitam emendaverit]" (TTP, V, p. 92).

Em sintonia com o que até agora dissemos, em particular com a quarta conclusão que tiramos do Escólio da proposição V, P Io, e à luz dessa passagem, podemos dizer que, se Espinosa fez como que um desvio no parágrafo I7 do Tratado da Emenda do Intelecto para ali introduzir as regras de vida, é porque a emenda do intelecto não é senão figura da emenda da vida. É essa última, e não aquela, que é virtualmente universal do ponto de vista prático: ao vulgo também é dada a possibilidade de seguir a verdadeira regra de vida ${ }^{31}$.

Tal é, para nós, o ponto central. No entanto, todas as consideraçóes até aqui feitas sobre a regra de vida tomam-na em sua dimensão ex proprio decreto, ou seja, como lei divina. Resta examinar a outra dimensão da regra de vida, associada à lei humana, o que faremos aqui apenas brevemente ${ }^{32}$. Trata-se de uma dimensão social e, em última instância, política.

A proposição IV, P 37 afirma que "o bem que cada um que segue a virtude apetece para si, ele também o desejará para os outros homens, e tanto mais quanto maior conhecimento de Deus ele tiver”. Em seu segundo Escólio, Espinosa explica a gênese da sociedade:

\footnotetext{
${ }^{30}$ Até o presente momento, não localizamos, nem entre os principais comentadores de Espinosa, nem entre os comentários a que tivemos acesso dedicados especificamente ao Tratado Teológico-Político, sequer mençáo ao conceito em questão. Cf. Bagley, 2008; Chaui, 2000, 2003, 20II, 2016; Deleuze, 1968, 2002; James, 20I2; Mathéron, 1988, 20II; Melamed, Rosenthal, 20I0; Moreau, 1994, 2003; Negri, 1993, 2002, 2016.

${ }^{31}$ Vale aqui acrescentar: “[...] nele [Jeremias] se afirma que Deus se arrepende da sentença proferida contra ou a favor dos homens quando estes desejam mudar os seus costumes e a sua maneira de viver [modum vivendi]. Em contrapartida, náo há nada que Paulo ensine mais abertamente que a ideia de que os homens não possuem nenhum domínio sobre as tentaçôes da carne a náo ser por uma especial vocação e graça de Deus" (Ibid. , II, p. 47). Sobre a vocaçáo ou graça de Deus, atentar para o que é dito no capítulo XIV: "Finalmente, Deus perdoa os pecados aos que se arrependem: de fato, como não há ninguém que não peque, se não se admitisse que era assim, todos desesperariam da salvação e não teriam nenhum motivo para acreditar na misericórdia divina. Mas aquele que acredita firmemente que Deus, pela misericórdia e graça com que rege todas as coisas, perdoa os pecados dos homens, e que por esse motivo se inflama ainda mais de amor para com Deus, esse conhece verdadeiramente Cristo segundo o Espírito e Cristo está nele” (Ibid., XIV, p. 220). Cf. também Ibid., III, p. 52.

${ }^{32}$ Esse ponto foi examinado por nós em outro trabalho, já submetido à publicação.
} 
Mas de que maneira pode ocorrer que os homens, que são necessariamente submetidos aos afetos (pelo corol. da prop. 4 desta parte), inconstantes e variáveis (pela prop. 33 desta parte), possam tornar seguros uns aos outros e ter confiança uns nos outros, é patente pela proposição 7 desta parte e pela proposição 39 da parte III. A saber, nenhum afeto pode ser coibido a não ser por um afeto mais forte e contrário ao afeto a ser coibido, e cada um abstémse de causar dano por temor de um dano maior. É portanto por esta lei que a Sociedade poderá firmar-se, desde que reivindique para si o direito que cada um tem de se vingar e de julgar sobre o bem e o mal; e por isso tenha o poder de prescrever uma regra comum de vida [communem vivendi rationem], de fazer leis e firmá-las não pela razão, que não pode coibir os afetos (pelo esc. da prop. I7 desta parte), mas por ameaças. E esta Sociedade, que se firma pelas leis e pelo poder de se conservar, é denominada Civitas, e aqueles que são defendidos pelo direito dela, Cidadãos (E, IV, P 37, Esc. 2).

O que dessa passagem interessa aqui notar é que o poder da sociedade para prescrever uma "regra comum de vida" não advém de uma transferência de poder, mas do que podemos denominar como o conatus comum: pelo esforço de perseverar na existência, cada um abstém-se de causar dano aos demais por temor de um dano maior. Por isso mesmo, quem prescreve não é alguém para quem o poder for transferido, mas a sociedade.

Por sua vez, o Tratado Politico estabelece a principal diferença entre o estado civil e o estado de natureza: naquele, "todos temem as mesmas coisas e é idêntica para todos a causa de segurança e a regra de vida [vivendi ratio]". Espinosa ainda argumenta que, no estado civil, "quem decide acatar tudo o que a Civitas manda, seja porque tema a potência desta ou porque ama a tranquilidade, esse atende realmente, de acordo com o seu engenho [ex suo ingenio], à sua segurança e ao seu interesse [utilitati]" (TP, III, 13$)^{33}$.

Levando-se em conta essas duas passagens, parece que a metáfora da rédea empregada no Tratado Teológico-Político, para além de seu contorno retórico, não permite concluir que a lei humana escraviza. Primeiro, porque a regra comum de vida, na gênese da sociedade, não é prescrita para um transcendente a quem foi transferido o poder, mas por cada um e por todos. Segundo, porque aquele que segue a lei, desde que esta não se torne odiosa e não produza o afeto de indignação, atende ao seu interesse.

Dito isso, temos agora elementos suficientes para sustentar por que e em que sentido a ratio vivendi é o conceito do qual o sábio é imagem. Ela é o viver sob a

33 Tanto para um homem como para uma civitas, a melhor regra de vida é aquela que é prescrita pela razão (Ibid., V, I). Em outras passagens do Tratado Político, Espinosa empregará os termos "vida em concórdia" (Ibid., V, 2) e "cultivo da vida" (Ibid., V, 6) para se referir ao melhor imperium. 
conduta da razão na prática. Por ela o homem age da melhor maneira não por livrearbitrio nem por ter alçado à liberdade da mente, nem por ter tido o intelecto emendado - até porque aquele cuja mente foi curada não precisa de nenhuma regra de $v i d a^{34}$ —, mas por ser levado a agir da melhor maneira, seja porque, ao buscar a liberdade ética ou a cura do intelecto, ele supóe como boas certas regras de vida ${ }^{35}$, seja por ser contido segundo determinadas regras de vida ${ }^{36}$. Não é marginal o fato de, ao introduzir o desvio de que falamos no Tratado da Emenda do Intelecto, Espinosa o abre com a expressão "porque é necessário viver" (TIE, I7). O conatus, da perspectiva individual, e o conatus comum, da perspectiva da sociedade, são razóes suficientes para a adoção, nos planos individual e social, de regras de vida.

Dessa maneira, e como conclusão, o "verdadeiro sábio", para usar a terminologia de Espinosa, é menos aquele que frui, como um asceta, do que aquele que usufrui ${ }^{37}$. Por sua vez, a chamada "beatitude", ou "felicidade", ou "salvação", ou "sabedoria", ou "tranquilidade do ânimo" e outros nomes que se dá para o mesmo, pois ao fim e ao cabo todos esses nomes remetem ao mesmo, podem ser alcançadas não só filosoficamente, segundo os passos da Ética, mas também pela piedade ${ }^{38}$. Em um caso e no outro, é igualmente através de uma regra de vida ou do esforço por emendar a vida que se chega à "verdadeira vida" 39 .

Tal ordem de questôes não é de menor importância para a política e a história — razão pela qual quisemos dedicar algumas linhas, ainda que brevemente, à regra comum de vida. Ao debruçar-se sobre esse domínio, nosso autor recusa a imagem tradicional da política como campo da obediência, o que requererá afastar não ape-

\footnotetext{
${ }^{34}$ Segundo o TIE, se "regra de vida" supōe o esforço por "colocar o intelecto no caminho reto" — sendo, dessa forma, um conatus da mente - , ela só se faz necessária porque o intelecto náo foi ainda curado.

35 TIE, 17.

36 "Ou que Moisés lhes tenha ensinado mais do que uma norma de vida, não na qualidade de filósofo, de maneira que fossem de livre vontade coagidos a praticar o bem" (TTP, II, p. 45); "A fé não requer tanto dogmas verdadeiros como dogmas piedosos, isto é, que levem o ânimo à obediência mesmo que em muitos deles não haja uma sombra de verdade: o que é preciso é que aquele que os abraça ignore que eles são falsos, pois caso contrário tornar-se-ia forçosamente insubmisso" (Ibid. , XIV, p. 2I8).

${ }^{37}$ Tales de Mileto náo é descrito como aquele que frui da beatitude de maneira contínua e irreversível, mas como aquele que usufrui das riquezas com moderatio (Ep. 44). Para uma leitura contrária à nossa, cf. Balibar, I990, p. II.

38 "Deus náo exige aos homens, através dos profetas, que conheçam dele outra coisa que não seja a sua divina justiça e caridade, quer dizer, aqueles atributos que os homens podem imitar mediante uma certa regra de vida. [...] quem tem a virtude da caridade possui realmente Deus e o conhece" (TTP, XIII, p . 2II ); "Deus é o único modelo da verdadeira vida" (Ibid. , XIII, p. 2I2); "Existe um Deus, isto é, um ser supremo, sumamente justo e misericordioso, modelo da verdadeira vida [...]. Deus, isto é, esse modelo de verdadeira vida" (Ibid. , XIV, p . 219); "O culto e a obediência a Deus consistem unicamente na justiça e na caridade, isto é, no amor para com o próximo. [...] Só aqueles que obedecem a Deus, seguindo essa norma de vida, obtêm a salvação" (Ibid., XIV, p. 22).

${ }^{39}$ Para uma leitura contrária à nossa, cf. Paula, 2009.
} 
nas a imagem hobbesiana do "súdito obediente" (Hobbes, I999, p. 78), mas também as figuras do "sábio ordenador", a quem compete "ordenar e julgar" [ordinare et iudicare] (Tomás de Aquino, Suma Teológica, I, I, 6), bem como do "sábio surdomudo" [chaham harashim] (Maimônides, Guia dos Perplexos, I, XXXIV), que detém o domínio das formas de regime político.

\section{Referências bibliográficas}

Balgley, P. (2008). Philosophy, Theology, and Politics: A Reading of Benedict Spinoza's Tractatus Theologico-politicus. Supplements to The Journal of Jewish thought and philosophy v. 6. Koninklijke Brill NV: Leiden.

Balibar, E. (1990). "Ultimi Barbarorum - Espinoza: o temor das massas". Tradução de B. P. Neto. Discurso, n. 18, pp. 7-35.

Chaui, M. (2000). A nervura do real. Imanência e liberdade em Espinosa (Vol. I Imanência). São Paulo: Companhia das Letras.

Chaui, M. (20I6). A nervura do real II. Imanência e liberdade em Espinosa (Vol. 2 - Liberdade). São Paulo: Companhia das Letras.

Chaui, M. (20II). Desejo, paixão e ação na Ética de Espinosa. São Paulo: Companhia das Letras.

Chaui, M. (2003). Politica em Espinosa. São Paulo: Companhia das Letras.

Deleuze, G. (2002). Espinosa: filosofia prática. São Paulo: Escuta.

Deleuze, G. (1968). Spinoza et le problème de l'expression. Paris: Les Éditions de Minuit.

Espinosa, B. (2012). Breve tratado de Deus, do homem e do seu bem-estar. Tradução e notas E. Â. da Rocha Fragoso; L. C. Oliva. Belo Horizonte: Autêntica Editora.

Espinosa, B. (20I2). "Carta no 44”, Cadernos de Ética e Filosofia Política, n. 20. Tradução, introdução e notas de A. David, pp. I78-I8I.

Espinosa, B. (20I5). Ética. Tradução de Grupo de Estudos Espinosanos. São Paulo: Editora da Universidade de Sáo Paulo.

Espinosa, B. (2015). Princípios de filosofia cartesiana e Pensamentos metafísicos. Tradução de H. Santiago, L. C. Oliva. Belo Horizonte: Autêntica.

Espinosa, B. (2015). Tratado da emenda do intelecto. Tradução de Cristiano Novaes de Rezende. Campinas: Editora da Unicamp.

Espinosa, B. (2009). Tratado Político. Tradução de D. P. Aurélio. São Paulo: Martins Fontes.

Espinosa, B. (2003). Tratado Teológico-político. Tradução de D. P. Aurélio. São Paulo: Martins Fontes.

Espinosa, B. (2012). Traité théologico-politique. Tradução de J. Lagrée et P.-F. Moreau. Paris: Presses Universitaires de France. 
Espinosa, B. (1972). Spinoza Opera. Tradução de Heidelberger Akademie der Wissenschaften. Heidelberg: C. Winter.

Hobbes, T. (1999) Leviatã. Tradução de J. P. Monteiro e M. B. N. da Silva. São Paulo: Editora Nova Cultura.

James, S. (2012). Spinoza on Philosophy, Religion, and Politics. The TheologicoPolitical Treatise. New York: Oxford University Press.

James, S. (2003). Spinoza et le spinozisme. Paris: Presses Universitaires de France.

Mainônides, M. (1998). Guia de Perplejos. D. G. Mazeo (ed.). Madrid: Editorial Trotta.

Mathéron, A. (20II). Études sur Spinoza et les philosophies de l'âge classique. Lyon: ENS Éditions.

Mathéron, A. (1988). Individu et communauté chez Spinoza. Paris: Les Éditions du Minuit, Nouvelle Édition.

Melamed, Y. Y., Rosenthal, M. A. (2010). Spinoza's 'theological-political treatise': a critical guide. New York: Cambridge University Press.

Moreau, P.-F. (1994). Spinoza: l'experience et l'éternité. Paris: Presses Universitaires de France.

Moreau, P.-F. (2003). Spinoza et le spinozisme. Paris: Presses Universitaires de France.

Negri, A. (1993). A anomalia selvagem: poder e potência em Spinoza. Rio de Janeiro: Ed. 34.

Negri, A. (2002). O poder constituinte: ensaio sobre as alternativas da modernidade. Rio de Janeiro: Ed. DP\&A.

Negri, A. (2016). Espinosa subversivo e outros escritos. Belo Horizonte: Autêntica.

Paula, M. F. (2009). Alegria e Felicidade. A experiência do processo libertador em Espinosa. (Tese de Doutorado). Departamento de Filosofia, Faculdade de Filosofia, Letras e Ciências Humanas da USP.

De Aquino, T. (1952). The Summa Theologica of Saint Thomas Aquinas. Tradução de Fathers of the English Dominican Province. Chicago: London: Toronto: William Benton, Publisher. Encyclopaedia Britannica Inc. (Great Books of the Western World, 19-20).

De Aquino, T. Corpus Thomisticum. Subsidia studii ab Enrique Alarcón collecta et edita. Disponível em <http://www.corpusthomisticum.org $>$. 